\title{
A Case of Preleukemic Chronic Myeloid Leukemia Following Chemotherapy and Autologous Transplantation for T-lymphoblastic Lymphoma
}

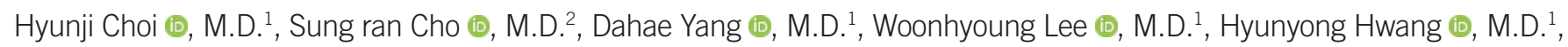

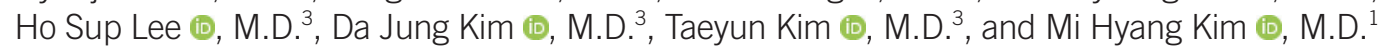

${ }^{1}$ Department of Laboratory Medicine, Kosin University College of Medicine, Busan, Korea; ${ }^{2}$ Department of Laboratory Medicine, Ajou University of Medicine, Suwon, Korea; ${ }^{3}$ Department of Internal Medicine, Kosin University College of Medicine, Busan, Korea

\section{Dear Editor:}

Secondary hematologic malignancy associated with chemotherapy or radiotherapy is common and mostly involves AML or MDS. However, therapy-related CML (tr-CML) is relatively rare as the progenitor cells in CML are less susceptible to DNA damage owing to their quiescent characteristics [1, 2] and the oncogene is relatively unified to Philadelphia chromosome (Ph), which harbors the BCR-ABL1 gene [3]. A previous study on trCML revealed that the average time for $C M L$ development following the first course of therapy is 48 months (range: 23 to 192 months) [2]. tr-CML has been shown to develop following radiotherapy and/or chemotherapy wherein alkylating agents or topoisomerase inhibitors are mostly used [2, 4]. tr-CML has been previously reported in solid tumors, lymphoma, multiple myeloma, etc. [2-5]. Among them, Hodgkin's lymphoma (HL) was the most common primary malignancy followed by CLL [2]. Uterine, cervical, ovarian, and breast cancers were also common primary malignancies in tr-CML [4]. The major BCR-ABL1 is a common fusion gene in tr-CML, and JAK2-BCR has been reported occasionally $[3,5]$. The clinical course of tr-CML seems similar to that of de novo CML [4]. Most patients pre- sented clinical features of CML such as leukocytosis or anemia [2-5].

A few cases of preleukemic CML (termed "preclinical," "asymptomatic," or "smoldering" $\mathrm{CML}$ ), which is characterized by the presence of $B C R-A B L 1$ without clinical features of $C M L$, have been reported. However, most cases were not associated with cytotoxic therapy [6-8]. To the best of our knowledge, this is the first case of preleukemic CML related to cytotoxic therapy (therapy-related preleukemic CML) in Korea. Until now two cases of therapy-related preleukemic CML have been reported worldwide (Table 1) [9, 10]. Our case is unique because we confirmed normal karyotype before chemotherapy, suggesting that the therapy induced preleukemic CML. This study was approved by the Institutional Review Board of Kosin University Gospel Hospital, Busan, Korea (KUGH 2019-12-007) that waived informed consent from the patient.

A 37-year-old man visited the Kosin university Gospel hospital presenting with a mass in his left oropharynx in November 2016 and was diagnosed as having T-lymphoblastic lymphoma (LBL). He showed normal karyotype, 46,XY [20], in his bone marrow with no evidence of lymphoma involvement. He underwent a
Received: November 5, 2019

Revision received: January 14, 2020

Accepted: March 13, 2020

Corresponding author: Mi Hyang Kim, M.D.

Department of Laboratory Medicine, Kosin University Gospel Hospital,

262 Gamchen-ro, Seo-gu, Busan 49267, Korea

Tel: +82-51-990-6373, Fax: +82-51-990-3034

E-mail: mihakimp@hanmail.net

\section{(c) (1) $\Theta$}

(C) Korean Society for Laboratory Medicine

This is an Open Access article distributed under the terms of the Creative Commons Attribution Non-Commercial License (https://creativecommons.org/licenses/by-nc/4.0) which permits unrestricted non-commercial use, distribution, and reproduction in any medium, provided the original work is properly cited. 
Table 1. Patients developing therapy-related preleukemic CML

\begin{tabular}{|c|c|c|c|c|c|c|c|c|c|c|}
\hline \multirow[b]{2}{*}{ Patient } & \multirow[b]{2}{*}{ Reference } & \multicolumn{5}{|c|}{ ID state } & \multicolumn{4}{|c|}{ preleukemic CML state } \\
\hline & & $\begin{array}{l}\text { Age } \\
\text { (yr) }\end{array}$ & Sex & ID & $\begin{array}{c}\text { BM } \\
\text { cytogenetics }\end{array}$ & $\begin{array}{l}\text { Type of } \\
\text { therapy }\end{array}$ & $\begin{array}{l}\text { Interval ID- } \\
\text { preleukemic } \\
\text { CML }\end{array}$ & Patient's status & BM cytogenetics & Follow-up \\
\hline 1 & Berman et al. [9] & 82 & $M$ & CLL & NT & CTx & 7 years & $\begin{array}{l}\text { Newly diagnosed } \\
\text { MCL }\end{array}$ & $\begin{array}{l}\text { 47,XY,t(9;22)(q34;q11.2),+mar[4]/ } \\
\quad 46, X Y[16]\end{array}$ & $\begin{array}{l}\text { / Developed clinical } \\
\text { CML } 8 \text { months later }\end{array}$ \\
\hline 2 & $\begin{array}{l}\text { Bolaños-Meade } \\
\text { et al. [10] }\end{array}$ & 35 & M & $H L$ & NT & $\mathrm{CTx}+\mathrm{RTx}$ & 14 months & $\begin{array}{l}\text { Preparing } \\
\text { autologous SCT }\end{array}$ & $46, X Y, t(9 ; 22)(q 34 ; q 11)[1] / 46, X Y[6]$ & $\begin{array}{l}\text { Developed clinical } \\
\text { CML } 16 \text { months later }\end{array}$ \\
\hline 3 & Present case & 37 & M & T-LBL & $46, \mathrm{XY}[20]$ & CTx & 32 months & Relapsed T-LBL & 46,XY,t(9;22)(q34;q11.2)[15]/46,XY[5] & $\begin{array}{l}\text { Regular follow-up } \\
\text { proceeding for } 8 \\
\text { months }\end{array}$ \\
\hline
\end{tabular}

Abbreviations: ID, initial diagnosis; BM, bone marrow; MCL, mantle cell lymphoma; HL, Hodgkin lymphoma; T-LBL, T-lymphoblastic lymphoma; CTx, chemptherapy; RTx, radiotherapy; SCT, stem cell transplantation; NT, not tested.
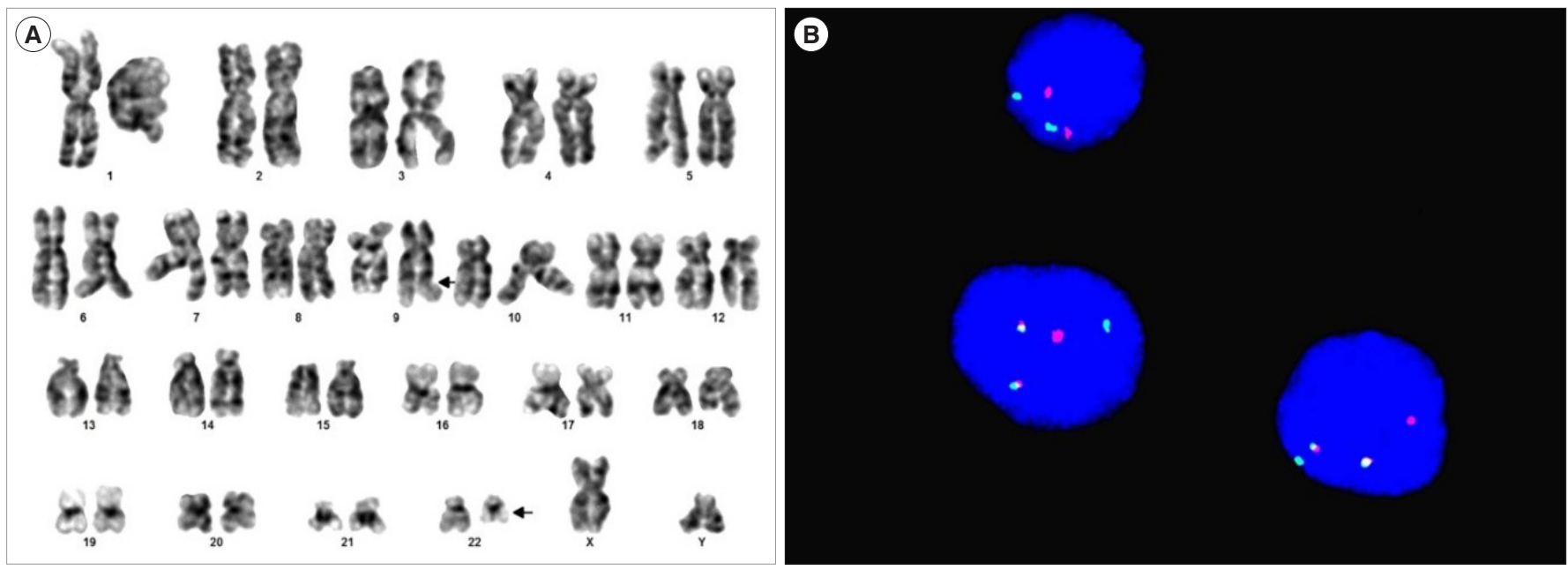

Fig. 1. Patient's clinical features. (A) The karyotype analysis showed 46,XY,t(9;22)(q34;q11.2) in 15 of 20 cells evaluated (arrow). (B) The FISH study revealed fusion of $A B L 1$ and $B C R$ genes in $76.5 \%$ of interphase.

left tonsillectomy and four cycles of systemic chemotherapy. The chemotherapy regimens included: one cycle of methotrexate, cytarabine, and dexamethasone; two cycles of cyclophosphamide, vincristine, doxorubicin, and dexamethasone; one cycle of methotrexate and cytarabine; and a final cycle of etoposide, methylprednisolone, cytarabine, and cisplatin. He achieved complete remission in December 2016 and subsequently underwent autologous stem cell transplantation in May 2017 after conditioning with busulfan, etoposide, and cyclophosphamide.

The lymphoma relapsed in his right tonsil in July 2019. The complete blood counts were as follows: Hb $141 \mathrm{~g} / \mathrm{L}$, platelets $240 \times 10^{9} / \mathrm{L}$, and leukocytes $6.28 \times 10^{9} / \mathrm{L}$ with $34 \%$ segmented neutrophils, $1 \%$ band neutrophils, 53\% lymphocytes, 5\% monocytes, $5 \%$ eosinophils, and $2 \%$ basophils. Bone marrow examination showed no evidence of $\mathrm{CML}$ or lymphoma (the myeloid:erythroid ratio was 3.4:1).

The differential counts of the bone marrow aspirate were as follows: myeloblasts, 1.8\%; promyelocytes, 1.8\%; myelocytes, 14.3\%; metamyelocytes, 15.4\%; band neutrophils, 15.0\%; segmented neutrophils, 16.1\%; eosinophils, 2.5\%; basophils, 0.5\%; proerythroblasts, $0.5 \%$; basophilic erythroblasts, $0.9 \%$; polychromatic erythroblasts, $10.2 \%$; orthochromatic erythroblasts, 8.2\%; lymphocytes, 8.6\%; monocytes, 1.6; and histiocytes, 2.5\%. However, a 46,XY,t(9;22)(q34;q11.2)[15]/46,XY[5] karyotype was detected (Fig. 1A). Additionally, FISH analysis using the locus-specific identifier BCR/ABL ( $A B L 1)$ translocation, dual fusion probe (Cytocell, Cambridge, UK) revealed the $B C R$ and $A B L 1$ gene fusion in $76.5 \%$ of interphases (Fig. 1B). Real-time PCR (Qiagen, Marseille, France) analysis revealed a normalized copy number of 29.5 for minor BCR-ABL1 (e1a2). 
An additional real-time PCR for relapsed lymphoma was considered; however, the residual tonsillar biopsy sample was insufficient. Moreover, we attempted to identify BCR-ABL1 retrospectively from the initial bone marrow sample and lymphoma tissue which were obtained in 2016; however, this proved unfeasible. The patient was diagnosed as having recurrent T-LBL and preleukemic CML. He was treated for relapsed lymphoma; regular examination for preleukemic CML was scheduled without tyrosine kinase inhibitor therapy.

To date, only two cases of therapy-related preleukemic CML have been reported (Table 1) [9, 10]. In one case, a 32-year-old man with $\mathrm{HL}$ received radiotherapy and chemotherapy. After 22 months, the presence of $B C R-A B L 1$ was detected and the patient was diagnosed as having preleukemic CML that progressed to clinical CML 16 months later [9]. The other case involved an 82-year-old man diagnosed as having mantle cell lymphoma (MCL). He had a medical history of CLL, which had been treated with chemotherapy seven years previously and did not exhibit any clinical features; however, BCR-ABL1 was detected when he was diagnosed as having MCL. He was diagnosed as having preleukemic CML, which developed into clinical CML within eight months [10]. However, in both cases, the presence of the $B C R-A B L 1$ fusion gene was not evaluated before initial therapy. In contrast, in our study, chemotherapy-induced preleukemic CML was supported by the presence of normal chromosomes in the patient's bone marrow karyotype before chemotherapy. There is no consensus on the standard treatment for preleukemic CML. However preemptive tyrosine kinase inhibitor (TKI) therapy is often considered and may delay the transformation to clinical CML [6-8].

This report suggests that BCR-ABL1 clones can be asymptomatic after cytotoxic therapy and require some time before progression to clinical CML. During preleukemic CML period TKI therapy can be used preemptively. We believe that this is the first reported case of preleukemic CML that occurred post cytotoxic therapy for T-LBL.

\section{ACKNOWLEDGEMENTS}

None.

\section{AUTHOR CONTRIBUTIONS}

HC, SC, and DHY conceived and designed the study, searched the scientific literature, interpreted the data, and wrote and revised the report. SC provided technical support for additional

tests. WL and HH designed the study, revised the report, and gave administrative support. HSL, DJK, and TK contributed to the interpretation of clinical data. MHK supervised the study and revised the report.

\section{CONFLICTS OF INTEREST}

The authors declare no conflicts of interest.

\section{RESEARCH FUNDING}

None declared.

\section{ORCID}

Hyunji Choi

Sung ran Cho

Dahae Yang

Woonhyoung Lee

Hyunyong Hwang

Ho Sup Lee

Da Jung Kim

Taeyun Kim

Mi Hyang Kim https://orcid.org/0000-0002-6453-7099
https://orcid.org/0000-0001-8898-3301
https://orcid.org/0000-0003-0606-2037
https://orcid.org/0000-0002-2863-3788
https://orcid.org/0000-0003-0662-3041
https://orcid.org/0000-0001-5974-6884
https://orcid.org/0000-0003-2375-8140
https://orcid.org/0000-0001-7786-5051
https://orcid.org/0000-0002-4684-970X

\section{REFERENCES}

1. Gale RP, Hlatky L, Sachs RK, Radivoyevitch T. Why is there so much therapy-related AML and MDS and so little therapy-related CML? Leuk Res 2014;38:1162-4.

2. Aguiar RC. Therapy-related chronic myeloid leukemia: an epidemiological, clinical and pathogenetic appraisal. Leuk Lymphoma 1998;29:1726.

3. Lee HY, Lee KH, Hyun MS, Kim MK, Koh, SA, Cho HS. Chronic myeloid leukemia as a secondary malignancy after diffuse large B-cell lymphoma. Korean J Intern Med 2014;29:250-2.

4. Waller CF, Fetscher S, Lange W. Treatment-related chronic myelogenous leukemia. Ann Hematol 1999;78:341-54.

5. Millett R, Aggarwal A, Tabbara I, Nassereddine S. Chronic myeloid leukemia as secondary malignancy following the treatment of Hodgkin lymphoma: a case series. Anticancer Res 2019;39:4333-5.

6. Gheith S, Spranklin L, Agostino N. The clinical relevance of detection of $\mathrm{BCR}-\mathrm{ABL}$ in an asymptomatic patient: a case report and review of the literature. Ann Clin Pathol 2015;3:1054.

7. Aye Le L, Loghavi S, Young KH, Siddiqi I, Yin CC, Routbort MJ, et al. Preleukemic phase of chronic myelogenous leukemia: morphologic and immunohistochemical characterization of 7 cases. Ann Diagn Pathol 2016;21:53-8.

8. Yoo DW, Park SH, Yi J, Kim IS, Kim HH, Chang CL, et al. Hidden "preleukemic phase" of chronic myeloid leukemia presenting without leukocytosis in the peripheral blood unrelated to chemotherapy in a patient diagnosed with diffuse large B cell lymphoma. Ann Lab Med 2017;37: 
443-5.

9. Berman E, Strife A, Wisniewski D, Desai S, Gulati S, Jhanwar S, et al. Duration of the preclinical phase of chronic myelogenous leukemia: a case report. Blood 1991;78:2969-72.
10. Bolaños-Meade J, Sarkodee-Adoo C, Khanwani SL. CML after treatment for lymphoid malignancy: therapy-related CML or coincidence? Am J Hematol 2002;71:139. 